\title{
Hubungan Antara Kepatuhan Minum Obat (MMAS-8) Dan Kualitas Hidup (WHOQOL-BREF) Penderita Tuberkulosis Di Puskesmas Di Kota Bandung
}

\author{
Dizky Ramadani Putri Papeo ${ }^{1,2^{*}}$, Maria Immaculata ${ }^{2}$, Iis Rukmawati ${ }^{*}$ \\ 1 Sekolah Farmasi, Institut Teknologi Bandung, Bandung, Indonesia. \\ 2 Jurusan Farmasi, Fakultas Olahraga dan Kesehatan, Universitas Negeri Gorontalo \\ ${ }^{3}$ Puskesmas Ibrahim Adji, Bandung, Indonesia. \\ ${ }^{*}$ E-mail:dizkyrputri@gmail.com
}

Article Info:

Received: 14 Maret 2021

in revised form: 26 April 2021

Accepted: 1 Mei 2021

Available Online: 1 Mei 2021

\begin{tabular}{l} 
Keywords: \\
Tuborculosis \\
MMAS-8 \\
WHOQOL-BREF \\
\hline Corresponding Author: \\
Dizky Ramadani Putri \\
Jurusan Farmasi \\
Fakultas Olaharaga dan \\
Kesehatan \\
Universitas Negeri Gorontalo \\
Kota Gorontalo \\
Indonesia \\
E-mail: \\
dizkyrputri@gmail.com
\end{tabular}

\begin{abstract}
Backgroumd: Tuberculosis (TB) is an infectious disease which is until now has not been able to be threated, i.e., because of patient nonadherence in taking anti-tuberculosis drug (ATD) Objective: The objective of this research is to study the relationship between patients adherence in taking ATD determined by MMAS-8 questionnaire with QoL of patient determined by WHOQOL questionnaire. Method: Tuberculosis patients who undergo treatment for at least 4 weeks are the subjects in this study. This study was conducted by a cross-sectional method using the MMAS-8 and WHOQOL-BREF questionnaire of tuberculosis patients at Ibrahim Adjiand Gumuruh primary health care during March - August 2018. Result: Based on MMAS-8 questionnaire filled out by 75 patients, there was $69 \%$ of high adherence, $15 \%$ moderate, and 16\% has low adherence in taking ATD. Of the 6 characteristic factors (i.e., age, sex, occupation, income, education and length of treatment), only gender (p0.01) and occupation (p0.03) factors that influence the patient adherence significantly. Based on MMAS-8 and WHOQOL-BREF questionnaire analyses, there is only psychological health aspect (domain two) that have a significant $(p=0.01)$ correlated with patient adherence. Conclusion: Based on the results, the psychological health of tuberculosis patients play an important role in patient adherence.
\end{abstract}




\begin{abstract}
ABSTRAK
Tuberkulosis (TB) merupakan penyakit menular yang disebabkan oleh bakteri mycobacterium tuberculosis sampai ini sulit diatasi antara lain oleh karena ketidakpatuhan penderita dalam meminum obat antituberkulosis (OAT). Penelitian ini bertujuan melihat hubungan antara kepatuhan minum OAT yang ditentukan dengan kuesioner MMAS-8 dengan kualitas hidup penderita yang ditentukan dengan kuesioner WHOQO-BREF. Penderita tuberkulosis yang telah menerima pengobatan minimal selama 4 minggu merupakan subjek dalam penelitian ini. Penelitian ini dilakukan secara cross-sectional menggunakan kuesioner MMAS-8 dan WHOQOL-BREF disertai wawancara terhadap penderita TB di dua puskesmas di kota bandung yaitu Ibrahim Adji dan Gumuruh selama bulan Maret - Agustus 2018. Hasil menunjukkan berdasarkan kuisioner MMAS-8 yang diisi 75 pasien (kuisioner) terdapat 69\% pasien tuberkulosis dengan kepatuhan tinggi, 15\% kepatuhan sedang dan 16\% kepatuhan rendah dalam minum OAT. Dari 6 faktor karakteristik yang dipelajari (usia, jenis kelamin, pekerjaan, pendapatan, pendidikan dan lama berobat) hanya dua faktor yang mempengaruhi secara signifikan kepatuhan minum OAT yaitu jenis kelamin $(p=0,01)$ dan pekerjaan $(p=0,03)$. Hasil analisis hubungan kuisioner MMAS-8 dan WHOQOL-BREF, diperoleh hanya domain 2 $(p=0,01)$ yang mencakup aspek kesehatan psikologis yang berpengaruh secara bermakna. Berdasarkan hasil penelitian ini hanya domain 2 yang mempengaruhi aspek kepatuhan minum obat.
\end{abstract}

Kata Kunci: Tuberkulosis, MMAS-8, WHOQOL-BREF

\title{
1. Pendahuluan
}

Tuberkulosis adalah penyakit infeksi menular yang disebabkan oleh bakteri mycobacterium tubeculosis. Kuman batang tahan aerobic dan tahan asam ini dapat merupakan organisme patogen ataupun saprofit [1]dan menyerang parenkim paru atau bagian lain dari tubuh manusia. Berdasarkan data WHO Global Tuberculosis Report [2]Indonesia menempati posisi kedua dengan kasus TBC tertinggi di dunia. Hal ini cukup memperihatinkan di mana pada data WHO Global Tuberculosis Report [3]Indonesia menempati peringkat ke 5, dan dikatakan cukup berhasil dalam penanggulangan TBC. Hingga tahun 2018, insidensi kasus TB di Indonesia belum menunjukkan penurunan, hal ini disebabkan masih banyak kasus yang belum terjangkau dan terdeteksi. Dalam kasus terdeteksi dan telah diobati kurangnya pemantauan dari petugas kesehatan terhadap kondisi pasien menjadi salah satu penyebab gagalnya terapi pengobatan yang sedang dilakukan. Berdasarkan studi Global Burden of Disease, TB menjadi penyebab kematian kedua di dunia. Angka TBC di Indonesia berdasarkan mikroskopik sebanyak 759 per 100.000 penduduk untuk usia di atas 15 tahun dengan jumlah penderita laki-laki lebih tinggi daripada perempuan, dan jumlah penderita yang tinggal di perkotaan lebih tinggi daripada di pedesaan [4]

Tuberkulosis (TB) disebabkan oleh Mycobacterium tuberculosis (M.Tb), yaitu kuman berbentuk batang dengan ukuran panjang 1-4/um dan tebal 0,3-0,6/um. Dinding bakteri ini terdiri dari asam lemak (lipid), peptigloglikan dan arabinomannan. Lipid yang terdapat pada dinding bakteri tersebut yang menyebabkan lebih tahan terhadap asam sehingga disebut bakteri tahan asam [1]. Banyak faktor yang berpengaruh terhadap terjadinya penyakit TB paru. Adapun faktor tersebut dapat berupa faktor individu, faktor kuman, dan faktor lingkungan. Faktor Individu dapat berupa berbagai hal yang mempengaruhi daya tahan tubuh individu tersebut, misalnya HIV/AIDS, Malnutrisi, Diabetes Melitus (DM), dan penggunaan immunosupresan. Faktor kuman dapat berupa konsentrasi kuman dan lama kontak dengan kuman. Faktor lingkungan dapat berupa ventilasi, kepadatan, serta pencahayaan dalam ruangan. Status gizi merupakan faktor penting dalam perjalanan penyakit infeksi. Status gizi buruk mampu memberikan risiko lebih besar pada seseorang yang terinfeksi bakteri TB. [5], [6]

Pengobatan tuberkulosis bertujuan untuk menyembuhkan pasien, mencegah kematian, mencegah kekambuhan, memutuskan rantai penularan dan mencegah terjadinya resistensi 
kuman terhadap obat anti tuberkulosis (OAT). Mikobakteri merupakan kuman tahan asam yang sifatnya berbeda dengan kuman lain karena tumbuhnya sangat lambat dan cepat sekali timbul resistensi bila terpajan dengan satu obat. Sifat lambat membelah yang dimiliki mikobakteri merupakan salah satu faktor yang menyebabkan perkembangan penemuan obat antimikobakteri baru jauh lebih sulit dan lambat dibandingkan antibakteri lain. Obat anti tuberkulosis yang digunakan terdiri atas, Rifampisin, INH, Pirazinamid, Streptomisin, Etambutol sebagai lini pertama dan lini kedua sebagai obat tambahan yaitu, Kanamisin, Kuinolon, obat lain dalam penelitian (makrolid, amoksisilin + asam klavulanat) serta derivate Rifampisin dan INH. Pengobatan TB diberikan dalam 2 tahap, yaitu tahap intensif dan lanjutan [1], [7]

Untuk menghentikan penyebaran tuberkulosis dibentuk suatu program pengendalian TB Nasional yang mengikutsertakan seluruh fasilitas kesehatan untuk berperan aktif. Directly Observed Treatment Shotcourse (DOTS) adalah strategi pengendalian tuberkulosis yang diawasi langsung oleh pengawas menelan obat yang sudah mendapat pengarahan oleh petugas TB. Hal paling mendasar untuk membantu kesembuhan pasien TB adalah kepatuhan pasien minum obat. Namun adanya beban fisik, psikis, sosial dan ekonomi bagi penderita tuberkulosis mendorong lambatnya proses kesembuhan dari pasien TB bahkan setelah program DOTS ini dijalankan.

Kepatuhan (adherence) adalah sejauh mana perilaku seseorang - minum obat, mengikuti diet, dan/atau melaksanakan perubahan gaya hidup, sesuai dengan rekomendasi yang telah disepakati dari penyedia layanan kesehatan [8]. Kepatuhan minum obat antituberkulosis erat dikaitkan dengan kualitas hidup pasien, namun banyaknya kasus kekambuhan harus menjadi bahan pemikiran apakah kepatuhan pasien dalam meminum obat akan memberi hasil yang signifikan terhadap kualitas hidup yang pasien tersebut [9]

Oleh karena itu dalam penelitian ini dilakukan analisis untuk mengetahui hubungan kepatuhan minum obat anti tuberkulosis terhadap kualitas hidup pasien penderita tuberkulosis di puskesmas di Kecamatan Batununggal Kota Bandung, di mana merupakan salah satu lokasi dengan jumlah kedatangan penderita TB yang selalu meningkat tiap bulan.

\section{Metode}

Desain penelitian ini adalah analitik observasional yang dilakukan secara cross-sectional untuk menganalisis faktor-faktor yang mempengaruhi tingkat kepatuhan pasien tuberkulosis. Data yang akan diambil berupa data kuantitatif. Data tersebut diperoleh dari hasil wawancara dan pengisian kuesioner pasien rawat jalan dan kunjungan ke rumah pasien. Dari data yang diperoleh akan dilakukan pengolahan yang menghasilkan data kualitas hidup pasien, tingkat kepatuhan pasien dan data untuk analisis faktor-faktor yang mempengaruhi kepatuhan pasien lupus. Subjek penelitian adalah pasien tuberkulosis rawat jalan di Puskesmas Ibrahim Adji dan Puskesmas Gumuruh yang memenuhi kriteria inklusi dan bersedia mengikuti penelitian yang membuktikan dengan informed consent. Cara pengambilan sampel dengan metode consecutive sampling, yaitu berasal dari subjek yang datang ke puskesmas dan memenuhi kriteria inklusi dan eksklusi hingga mencapai ukuran sampel yang dibutuhkan selama periode penelitian langsung.

\subsection{Populasi dan Sampel}

Populasi target penelitian ini adalah pasien yang didiagnosis Tuberkulosis dan terdaftar sebagai pasien rawat jalan Puskesmas Ibrahim Adji dan Puskesmas Gumuruh. Jumlah sampel yang ditentukan sebanyak 75 sampel [10]

\subsection{Kriteria Inklusi dan Eksklusi}

Kriteria inklusi dalam penelitian ini adalah penderita tuberkulosis yang sedang menerima pengobatan obat anti tuberkulosis minimal selama 4 minggu sejak tahap awal pengobatan, berusia lebih atau sama dengan 17 tahun dan mampu memahami instruksi secara lisan maupun tulisan. Sampel penelitian yang tidak digunakan adalah penderita tuberkulosis yang tidak bisa diajak berkomunikasi atau kondisinya tidak memungkinkan untuk diwawancarai. 


\subsection{Waktu dan Tempat Penelitian}

Penelitian dilaksanakan sejak Maret - Agustus 2018 bertempat di Puskesmas Ibrahim Adji, Puskesmas Gumuruh dan Kediaman Pasien

\subsection{Pengorganisasian Analisis Data}

Data hasil wawancara dimasukkan ke dalam kolom-kolom kuesioner yang telah tersedia yang meliputi data kerakteristik pasien, data tingkat kepatuhan pasien. Kuesioner yang digunakan untuk mengetahui tingkat kepatuhan pasien adalah kuesioner MMAS-8, sedangkan kuesioner kualitas hidup menggunakan kuisioner WHOQOL-BREF Kemudian hasil kuesioner yang diperolah dibagi menjadi 3 pengolahan, yaitu: pengolahan data tingkat kepatuhan pasien dengan menjumlahkan score MMAS-8, pengolahan korelasi data karakteristik pasien dengan tingkat kepatuhan menggunakan metode chi square, dan pengolahan hubungan kepatuhan pasien dalam mengonsumsi obat terhadap kualitas hidup pasien. Hasil dari pengolahan data tersebut kemudian dibandingkan terhadap teori yang telah ada.[11]

\section{Hasil dan Pembahasan}

\subsection{Tingkat Kepatuhan Pasien TB}

Jumlah seluruh subjek penelitian dalam penelitian ini sebanyak 75 orang. Seluruh subjek penelitian terdiagnosa tuberkulosis dan telah menerima terapi lebih atau sama dengan 4 minggu. Dari 75 subjek diperoleh tingkat kepatuhan tingkat kepatuhan tinggi sebesar 69\%, kepatuhan sedang $15 \%$ dan kepatuhan tinggi 16\%. Menurut WHO dalam konteks pengendalian TB, kepatuhan terhadap pengobatan merupakan tingkat ketaatan pasien yang memiliki riwayat pengambilan obat terapeutik terhadap resep pengobatan. Kepatuhan rata-rata pasien pada pengobatan jangka panjang terhadap penyakit kronis di negara maju hanya sebesar $50 \%$ sedangkan negara berkembang jumlah tersebut bahkan lebih rendah.[8], [12]

\subsection{Korelasi Usia dengan Kepatuhan Pasien TB}

Departemen Kesehatan RI menggolongkan usia menjadi 9, yaitu: masa balita (0-5 tahun), masa kanak-kanak (5-11 tahun), masa remaja awal (12-16 tahun), masa remaja akhir (17-25 tahun), masa dewasa awal (26-35 tahun), masa dewasa akhir (36-45 tahun), masa lansia awal (46-55 tahun), masa lansia akhir (56-65 tahun), dan masa manula (65-sampai atas). Dari 75 data yang diperoleh, pasien berada dalam rentang usia 17 hingga 71 tahun. Pada tabel 1 di bawah ini menunjukkan bahwa dari 75 data pasien, jumlah penderita tuberkulosis terbanyak berada pada usia remaja awal (23 orang) dan dewasa akhir ( 26 orang) di mana termasuk dalam kategori usia produktif.

Penelitian lain yang mendukung dilakukan oleh Laily [13]yang menunjukkan penderita TB paling banyak pada usia 26-45 tahun dan penelitian Panjaitan [14]menunjukkan rerata pasien TB berusia 44,2 tahun dengan kelompok tersering pada usia produktif 18-29 tahun. Umur produktif sangat berbahaya terhadap tingkat penularan karena pasien mudah berinteraksi dengan orang lain, mobilitas yang tinggi dan memungkinkan untuk menular ke orang lain serta lingkungan sekitar tempat tinggal. TB banyak terjadi pada usia dewasa dimungkinkan oleh dua penyebab. Pertama orang dewasa tersebut pernah terinfeksi TB primer dilingkungannya pada waktu kecil akan tetapi tidak dilakukan preventif dengan baik sehingga muncul pada saat dewasa. Kemungkinan yang kedua, adanya aktivitas dan lingkungan pekerjaan pada kelompok orang dewasa yang berinteraksi dengan penderita TB atau lingkungan yang memudahkan tertular TB.[13], [14] 
Tabel 1. Korelasi usia dengan tingkat kepatuhan

\begin{tabular}{|c|c|c|c|c|c|c|c|c|c|c|}
\hline \multirow{3}{*}{ Usia } & \multicolumn{6}{|c|}{ Kepatuhan } & \multirow{2}{*}{\multicolumn{2}{|c|}{ Total }} & \multirow{3}{*}{$\begin{array}{c}\mathrm{p} \\
\text { Value }\end{array}$} & \multirow{3}{*}{$\begin{array}{l}\text { Bobo } \\
\text { Total }\end{array}$} \\
\hline & \multicolumn{2}{|c|}{ Tinggi } & \multicolumn{2}{|c|}{ Sedang } & \multicolumn{2}{|c|}{ Rendah } & & & & \\
\hline & $\mathrm{n}$ & $\%$ & $\mathrm{n}$ & $\%$ & $\mathrm{~N}$ & $\%$ & $\mathrm{n}$ & $\%$ & & \\
\hline Masa & & & & & & & & & & \\
\hline $\begin{array}{l}\text { Remaja } \\
\text { Akhir } \\
\text { Masa }\end{array}$ & 15 & 28.8 & 4 & 36.4 & 4 & 33.3 & 23 & 30,7 & & 0,32 \\
\hline $\begin{array}{c}\text { Dewasa } \\
\text { Awal } \\
\text { Masa }\end{array}$ & 8 & 15.4 & 4 & 36.4 & 2 & 16.7 & 14 & 18,7 & & 0,22 \\
\hline $\begin{array}{l}\text { Dewasa } \\
\text { Akhir }\end{array}$ & 18 & 34.6 & 2 & 18.2 & 6 & 50.0 & 26 & 34,7 & 0.61 & 0,32 \\
\hline Masa & & & & & & & & & & \\
\hline $\begin{array}{c}\text { Lansia } \\
\text { Awal } \\
\text { Masa }\end{array}$ & 4 & 7.7 & 1 & 9.1 & 0 & 0.0 & 5 & 6,7 & & 0,06 \\
\hline $\begin{array}{l}\text { Lansia } \\
\text { Akhir }\end{array}$ & 4 & 7.7 & 0 & 0.0 & 0 & 0.0 & 4 & 5,3 & & 0,03 \\
\hline Manula & 3 & 5.8 & 0 & 0.0 & 0 & 0.0 & 3 & 4,0 & & 0,02 \\
\hline Total & 52 & 100.0 & 11 & 100.0 & 12 & 100.0 & 75 & 100,0 & & \\
\hline
\end{tabular}

Korelasi antara usia dan kepatuhan ditentukan dengan metode chi square dan didapatkan hasil nilai $\mathrm{p}=0,61(>0,05)$. Hal ini menunjukkan bahwa perbedaan usia tidak signifikan terhadap kepatuhan pasien dalam mengonsumsi obat. Dari hasil perhitungan persentase di atas didapatkan bahwa pasien yang memiliki tingkat kepatuhan tinggi dan rendah berada pada rentang usia remaja akhir dan dewasa akhir. Nilai bobot total menunjukkan nilai yang sama $(0,32)$ pada kelompok remaja akhir dan dewasa akhir

\subsection{Korelasi Jenis Kelamin dengan Kepatuhan Pasien Tuberkulosis}

Pada penelitian yang dilakukan Panjaitan [14] perbandingan jenis kelamin laki-laki dan perempuan yang menderita TB sebesar 3:2, Juga pada penelitian Jamayanti [15] bahwa jenis kelamin laki-laki menjadi kelompok paling banyak menderita TB dibandingkan perempuan. Hal ini menunjukkan keselaras dengan data dilapangan dari 75 penderita TB terdapat (46 orang) yang berjenis kelamin laki-laki dan (29 orang) berjenis kelamin perempuan. Ada beberapa penyebab seperti imunitas perempuan lebih tinggi dari laki-laki hingga perilaku kebiasaan merokok pada laki-laki. Merokok dapat menyebabkan peningkatan risiko terkena TB menjadi 2 kali. Merokok dapat merusak fungsi paru-paru dan menekan kekebalan adaptif individu. Penurunan imunitas ini berdampak pada respon pasien terhadap pengobatan TB.

Tabel 2. Korelasi jenis kelamin dengan tingkat kepatuhan

\begin{tabular}{|c|c|c|c|c|c|c|c|c|c|c|}
\hline \multirow{3}{*}{$\begin{array}{c}\text { Jenis } \\
\text { Kelamin }\end{array}$} & \multicolumn{6}{|c|}{ Kepatuhan } & \multirow{3}{*}{\multicolumn{2}{|c|}{ Total }} & \multirow{3}{*}{$p$ value } & \multirow{3}{*}{$\begin{array}{c}\text { Bobot } \\
\text { total }\end{array}$} \\
\hline & \multicolumn{2}{|c|}{ Tinggi } & \multicolumn{2}{|c|}{ Sedang } & \multicolumn{2}{|c|}{ Rendah } & & & & \\
\hline & $\mathrm{N}$ & $\%$ & $\mathrm{n}$ & $\%$ & $\mathrm{n}$ & $\%$ & & & & \\
\hline Laki-laki & 37 & 71 & 7 & 64 & 2 & 17 & 46 & 61 & & 0,6 \\
\hline Perempuan & 15 & 29 & 4 & 36 & 10 & 83 & 29 & 39 & 0,01 & 0,4 \\
\hline Total & 52 & 100 & 11 & 100 & 12 & 100 & 75 & 100 & & 1 \\
\hline
\end{tabular}


Korelasi antara jenis kelamin dan kepatuhan ditentukan dengan metode chi square dan didapatkan hasil nilai $\mathrm{p}=0,01(<0,05)$. Hal ini menunjukkan bahwa jenis kelamin secara signifikan berpengaruh terhadap kepatuhan pasien dalam mengonsumsi obat. Data di atas menunjukkan kepatuhan laki-laki lebih besar $(71 \%)$ daripada perempuan $(29 \%)$ dengan nilai bobot total menunjukkan bahwa laki-laki $(0,6)$ memiliki tingkat kepatuhan minum obat pun cukup besar dibandingkan perempuan $(0,4)$, hal ini bisa disebabkan karena kesadaran diri sebagai pencari nafkah dalam keluarga sehingga menjadi motivasi memperoleh kesembuhan. Secara epidemiologi terdapat perbedaan antara laki-laki dan perempuan dalam hal penyakit infeksi, progresivitas penyakit, insidens dan kematian akibat TB. Perkembangan penyakit juga mempunyai perbedaan antara laki-laki dan perempuan yaitu perempuan mempunyai penyakit lebih berat pada saat datang ke rumah sakit. Perempuan lebih sering terlambat datang ke pelayanan kesehatan dibandingkan dengan laki-laki. Hal ini mungkin berhubungan dengan aib dan rasa malu lebih dirasakan pada perempuan dibanding laki-laki. Perempuan juga lebih sering mengalami kekhawatiran akan dikucilkan dari keluarga dan lingkungan akibat penyakitnya. Hambatan ekonomi dan faktor sosial ekonomi kultural turut berperan termasuk pemahaman tentang penyakit paru

\subsection{Korelasi Pekerjaan dengan Kepatuhan Pasien Tuberkulosis}

Pekerjaan dapat mempengaruhi kondisi fisik dan imunitas tubuh, pasien TB yang mendapatkan terapi antituberkulosis umumnya memperlihatkan gejala efek samping obat, dari yang ringan hingga berat sehingga berakibat pada produktifitas pasien TB

Tabel 3. Korelasi pekerjaan dengan tingkat kepatuhan

\begin{tabular}{|c|c|c|c|c|c|c|c|c|c|c|}
\hline \multirow{3}{*}{ Pekerjaan } & \multicolumn{6}{|c|}{ Kepatuhan } & \multirow{2}{*}{\multicolumn{2}{|c|}{ Total }} & \multirow{3}{*}{$\begin{array}{c}\mathrm{p} \\
\text { value }\end{array}$} & \multirow{3}{*}{$\begin{array}{l}\text { Bobot } \\
\text { total }\end{array}$} \\
\hline & \multicolumn{2}{|c|}{ Tinggi } & \multicolumn{2}{|c|}{ Sedang } & \multicolumn{2}{|c|}{ Rendah } & & & & \\
\hline & $\mathrm{n}$ & $\%$ & $\mathrm{n}$ & $\%$ & $\mathrm{n}$ & $\%$ & $\mathrm{n}$ & $\%$ & & \\
\hline PNS/TNI/POLRI & 0 & 0,0 & 0 & 0,0 & 0 & 0,0 & 0 & 0,0 & & 0 \\
\hline $\begin{array}{c}\text { Karyawan } \\
\text { Swasta/Buruh }\end{array}$ & 33 & 63,5 & 8 & 72,7 & 8 & 66,7 & 49 & 65,3 & & 0,67 \\
\hline Petani/Peternak & 0 & 0,0 & 0 & 0,0 & 0 & 0,0 & 0 & 0,0 & & 0 \\
\hline Pelajar & 0 & 0,0 & 2 & 18,2 & 2 & 16,7 & 4 & 5,3 & 0,03 & 0,08 \\
\hline $\begin{array}{l}\text { Ibu Rumah } \\
\text { Tangga }\end{array}$ & 14 & 26,9 & 0 & 0,0 & 2 & 16,7 & 16 & 21,3 & & 0,16 \\
\hline $\begin{array}{c}\text { Pensiun/ } \\
\text { Pengangguran }\end{array}$ & 5 & 9,6 & 1 & 9,1 & 0 & 0,0 & 6 & 8,0 & & 0,07 \\
\hline Total & 52 & 100,0 & 11 & 100,0 & 12 & 10,0 & 75 & 100,0 & & \\
\hline
\end{tabular}

Korelasi antara pekerjaan dan kepatuhan ditunjukkan dengan nilai $p=0,03(<0,05)$. Hal ini menunjukkan ada korelasi antara pekerjaan dan kepatuhan pasien dalam mengonsumsi obat. Berdasarkan data persentase, tingkat kepatuhan pasien yang tinggi adalah karyawan swasta/buruh 63,5\% (33 orang) dengan nilai total bobot 0,67 . Hal sesuai dengan pernyataan Notoatmodjo [16] yang mengatakan lingkungan pekerjaan dapat menjadikan seseorang memperoleh pengalaman dan pengetahuan baik secara langsung maupun secara tidak langsung.

\subsection{Korelasi Pendapatan dengan Kepatuhan Pasien Tuberkulosis}

Pendapatan berperan dalam menopang kebutuhan hidup, pendapatan akan mempengaruhi aspek fisik, mental dan sosial pasien. Dari 75 Pasien pendapatan kurang dari 1 juta rupiah 36 orang, kisaran 1 juta - 3 juta 39 orang dan tidak terdapat pendapatan diatasnya. Penghasilan tersebut dipengaruhi oleh pekerjaan yang tidak menetap, pekerjaan dengan penghasilan berjumlah sedikit, dan berada pada sosial ekonomi yang rendah. Penghasilan yang tidak menetap mempengaruhi pola gaya hidup pasien sehingga tidak memenuhi gizi yang baik. Hal tersebut akan berpengaruh terhadap kondisi tubuh pasien lebih buruk. 
Tabel 4. Korelasi pendapatan dengan tingkat kepatuhan pasien tuberculosis

\begin{tabular}{|c|c|c|c|c|c|c|c|c|c|c|}
\hline \multirow{3}{*}{ Pendapatan } & \multicolumn{6}{|c|}{ Kepatuhan } & \multirow{2}{*}{\multicolumn{2}{|c|}{ Total }} & \multirow{3}{*}{$\begin{array}{c}\mathrm{p} \\
\text { value }\end{array}$} & \multirow{3}{*}{$\begin{array}{l}\text { Total } \\
\text { Bobot }\end{array}$} \\
\hline & \multicolumn{2}{|c|}{ Tinggi } & \multicolumn{2}{|c|}{ Sedang } & \multicolumn{2}{|c|}{ Rendah } & & & & \\
\hline & $\mathrm{n}$ & $\%$ & $\mathrm{n}$ & $\%$ & $\mathrm{n}$ & $\%$ & $\mathrm{n}$ & $\%$ & & \\
\hline$<1$ juta & 24 & 46,2 & 2 & 18,2 & 2 & 16,7 & 28 & 37,3 & & 0,31 \\
\hline 1-3 juta & 23 & 44,2 & 8 & 72,7 & 8 & 66,7 & 39 & 52,0 & 0.19 & 0,57 \\
\hline$>3$ juta & 5 & 9,6 & 1 & 9,1 & 2 & 16,7 & 8 & 10,7 & & 0,10 \\
\hline Total & 52 & 100,0 & 11 & 100,0 & 12 & 100,0 & 75 & 100,0 & & \\
\hline
\end{tabular}

Korelasi antara pendapatan dan kepatuhan ditunjukkan pada tabel di atas dengan nilai $p=0,19$ $(<0,05)$. Hal ini menunjukkan tidak ada korelasi yang signifikan antara pendapatan dan kepatuhan pasien mengonsumsi obat. Berdasarkan data persentase, tingkat kepatuhan pasien yang tinggi paling banyak adalah pada pasien dengan pendapatan terendah ( $24 \mathrm{orang})$ dan kepatuhan terendah pada kelompok pasien dengan pendapatan menengah dengan total bobot 0,57. Hasil ini tidak sesuai teori Gatchel [17] yang menyatakan tingkat pendapatan berhubungan dengan tingkat kepatuhan seseorang untuk minum obat secara teratur. Penelitian di Puskesmas di Kota Manado menunjukkan tidak ada hubungan antara tingkat pendapatan dan kepatuhan minum obat $(p=0,27)$.[18] Pada penelitian ini kelompok pasien dengan pendapatan rendah menyadari memiliki tingkat kepatuhan paling tinggi karena menyadari bahwa kesehatan yang terganggu dapat mengganggu besar pendapatan yang mereka peroleh sehingga ada kesadaran diri untuk patuh.

\subsection{Korelasi Pendidikan dengan Kepatuhan Pasien Tuberkulosis}

Pendidikan dapat membawa wawasan atau pengetahuan seseorang. Secara umum, seseorang yang berpendidikan lebih tinggi akan mempunyai pengetahuan yang lebih luas dibandingkan dengan seseorang yang tingkat pendidikannya rendah [16]. Pasien tuberkulosis yang menjadi sampel penelitian memiliki tingkat pendidikan yang beragam. Dari 75 pasien jumlah tingkat pendidikan SMP ( 25 orang) dan SMA (42 orang) lebih banyak dibandingkan lulusan SD (4 orang) dan perguruan tinggi (4 orang) Dari data tersebut dapat dilihat bahwa kebanyakan pasien TB yang berkunjung adalah pasien dengan pendidikan terakhir SMA dan SMP.

Tabel 5. Korelasi pendidikan dengan tingkat kepatuhan

\begin{tabular}{|c|c|c|c|c|c|c|c|c|c|c|}
\hline \multirow{3}{*}{ Pendidikan } & \multicolumn{6}{|c|}{ Kepatuhan } & \multirow{2}{*}{\multicolumn{2}{|c|}{ Total }} & \multirow{3}{*}{$p$ value } & \multirow{3}{*}{$\begin{array}{l}\text { Bobot } \\
\text { total }\end{array}$} \\
\hline & \multicolumn{2}{|c|}{ Tinggi } & \multicolumn{2}{|c|}{ Sedang } & \multicolumn{2}{|c|}{ Rendah } & & & & \\
\hline & $\mathrm{n}$ & $\%$ & $\mathrm{n}$ & $\%$ & $\mathrm{n}$ & $\%$ & $\mathrm{n}$ & $\%$ & & \\
\hline SD & 4 & 7,7 & 0 & 0,0 & 0 & 0,0 & 4 & 5,3 & & 0,03 \\
\hline SMP & 20 & 38,5 & 3 & 27,3 & 2 & 16,7 & 25 & 33,3 & & 0,31 \\
\hline SMA & 26 & 50,0 & 8 & 72,7 & 8 & 66,7 & 42 & 56,0 & 0,22 & 0,60 \\
\hline $\begin{array}{c}\text { Perguruan } \\
\text { Tinggi }\end{array}$ & 2 & 3,8 & 0 & 0,0 & 2 & 16,70 & 4 & 5,3 & & 0,04 \\
\hline Total & 52 & 100,0 & 11 & 100,0 & 12 & 100,0 & 75 & 100,0 & & \\
\hline
\end{tabular}

Korelasi antara pendidikan dan kepatuhan ditunjukkan ditunjukkan pada tabel di atas dengan nilai $p=0,22(>0,05)$. Hal ini menunjukkan tidak ada korelasi yang signifikan antara pendidikan dan kepatuhan pasien mengonsumsi obat. Data persentase menunjukkan tingkat kepatuhan tinggi dan rendah terdapat pada SMA $(50 \%$ dan $66,7 \%)$ di mana nilai bobot tolat sebesar 0,60. Tingkat pendidikan formal merupakan landasan seseorang dalam berbuat sesuatu, membuat lebih mengerti dan memahami sesuatu, atau menerima dan menolak sesuatu. 
Tingkat pendidikan formal juga memungkinkan perbedaan pengetahuan dan pengambilan keputusan. Penelitian yang di lakukan di Puskesmas Pancoran kebanyakan pasien yang tidak patuh berobat adalah pasien dengan pendidikan rendah, hal ini membuktikan bahwa memang benar tingkat pendidikan seseorang akan mempengaruhi pengetahuan seseorang, seperti mengenali rumah yang memenuhi syarat kesehatan dan pengetahuan penyakit TB Paru, sehingga dengan pengetahuan yang cukup maka seseorang akan mencoba untuk mempunyai perilaku hidup bersih dan sehat. Beberapa penelitian lain menunjukkan bahwa pasien dengan tingkat pendidikan yang lebih tinggi 78\% lebih kecil kemungkinannya untuk mematuhi obatobatan. Tingkat kepatuhan yang lebih rendah di antara yang berpendidikan lebih tinggi mungkin disebabkan oleh kombinasi faktor.[12][19]

\subsection{Korelasi Lama Pengobatan dengan Kepatuhan Pasien Tuberkulosis}

Pasien Tuberkulosis menjalani pengobatan rawat jalan minimal 6 bulan hingga 9-12 bulan. Pemeriksaan pertama dilakukan untuk mendeteksi adanya bakteri penyebab tuberkulosis untuk kemudian diberikan terapi pengobatan. Terapi pengobatan hanya diberikan jika pada pemeriksaan sputum (dahak) BTA terdapat nilai positif, ditunjang dengan foto rontgen, pemeriksaan darah harus mengikuti kontrol rutin untuk melihat bagaimana perkembangan penyakitnya dengan melihat hasil pemeriksaan laboratorium. Pasien akan diedukasi terkait terapi, bagaimana cara meminum obat, efek samping yang mungkin muncul dan penanganannya. Terapi terdiri atas dua fase, yaitu fase awal ( 2 bulan pertama) dan fase lanjutan (4-10 bulan). Fase 2 selesai, pasien umumnya akan dilakukan kontrol seperti yang dilakukan pada saat diagnosis untuk melihat ada tidak perubahan yang muncul.

Tabel 6. Korelasi lama masa pengobatan dengan tingkat kepatuhan

\begin{tabular}{|c|c|c|c|c|c|c|c|c|c|c|}
\hline \multirow{3}{*}{$\begin{array}{l}\text { Lama } \\
\text { Berobat }\end{array}$} & \multicolumn{6}{|c|}{ Kepatuhan } & \multirow{2}{*}{\multicolumn{2}{|c|}{ Total }} & \multirow{3}{*}{$\begin{array}{c}\mathrm{p} \\
\text { value }\end{array}$} & \multirow{3}{*}{$\begin{array}{l}\text { Bobot } \\
\text { Total }\end{array}$} \\
\hline & \multicolumn{2}{|c|}{ Tinggi } & \multicolumn{2}{|c|}{ Sedang } & \multicolumn{2}{|c|}{ Rendah } & & & & \\
\hline & $\mathrm{n}$ & $\%$ & $\mathrm{n}$ & $\%$ & $\mathrm{~N}$ & $\%$ & $\mathrm{n}$ & $\%$ & & \\
\hline $\begin{array}{l}\text { Tahap } \\
\text { Awal }\end{array}$ & 31 & 59,6 & 6 & 54,5 & 10 & 83,3 & 47 & 62,7 & & 0,61 \\
\hline $\begin{array}{l}\text { Tahap } \\
\text { Lanjut }\end{array}$ & 21 & 40,4 & 5 & 45,5 & 2 & 16,7 & 28 & 37,3 & 0,25 & 0,38 \\
\hline Total & 52 & 100,0 & 11 & 100,0 & 12 & 100,0 & 75 & 100,0 & & \\
\hline
\end{tabular}

Korelasi antara lama berobat dan kepatuhan ditunjukkan dengan nilai $p=0,25(>0,05)$. Hal ini menunjukkan tidak ada korelasi yang signifikan antara lama waktu berobat dan tingkat kepatuhan pasien mengonsumsi obat. Berdasarkan data persentase, tingkat kepatuhan tinggi dan rendah berada pada kategori pasien fase awal (59,6\% dan 62,7\%). Kepatuhan tinggi oleh pasien disebabkan karena pengawasan yang intensif dari pengawas minum obat pada dua bulan pertama dan frekuensi obat yang harus diminum setiap hari sehingga dapat dihindarkan dari lupa minum obat. Namun seiring berjalannya pengobatan kepatuhan menurun karena rasa jenuh yang diakibatkan oleh lamanya pengobatan dan munculnya efek samping, seperti nyeri sendi, munculnya rasa gatal, mual dan muntah.

\subsection{Hubungan Kepatuhan Minum Obat dan Kualitas Hidup Pasien}

Kualitas hidup (Quality of Life) merupakan persepsi individu dalam hidupnya yang ditinjau dari konteks budaya, perilaku dan sistem nilai di mana mereka tinggal dan berhubungan dengan standar hidup, harapan, kesenangan, dan penilaian individu terhadap posisi mereka dalam kehidupan. Instrumen WHOQOL-BREF merupakan ringkasan dari WHOQOL-100 yang lebih praktis di mana terdapat 26 yang terdiri dari 4 domain yaitu aspek kesehatan fisik, aspek kesehatan psikologis, aspek hubungan sosial, dan aspek kondisi lingkungan. Instrumen MMAS8 merupakan alat ukur untuk melihat kepatuhan minum obat.[11], [20]

Dari 75 jumlah penderita tuberkulosis yang menerima terapi OAT diketahui $69 \%$ memiliki kepatuhan tinggi sehingga perlu dilihat adakah nilai yang bermakna antara hubungan 
kepatuhan minum obat dan kualitas hidup penderita setelah mendapatkan pengobatan selama minimal atau lebih dari 4 minggu. Penelitian yang dilakukan Safii dkk. [21] di Puskesmas Padasuka Bandung menunjukkan kualitas hidup pasien patuh dan tidak patuh berada dalam kategori sedang dan terdapat 5 orang pasien yang memiliki kualitas hidup buruk.

Tabel 7. Hubungan kepatuhan minum obat terhadap kualitas hidup pasien TB

\begin{tabular}{|c|c|c|c|c|c|c|c|c|}
\hline & \multirow{3}{*}{ Kepatuhan } & \multicolumn{4}{|c|}{ Kualitas Hidup } & \multirow{2}{*}{\multicolumn{2}{|c|}{ Total }} & \multirow{3}{*}{$\begin{array}{c}\mathrm{p} \\
\text { value }\end{array}$} \\
\hline & & \multicolumn{2}{|c|}{ Buruk } & \multicolumn{2}{|c|}{ Baik } & & & \\
\hline & & $\mathrm{n}$ & $\%$ & $\mathrm{n}$ & $\%$ & $\mathrm{n}$ & $\%$ & \\
\hline \multirow{4}{*}{ Domain 1} & Rendah & 7 & 58,3 & 5 & 41,7 & 12 & 100 & \multirow{4}{*}{0,18} \\
\hline & Sedang & 10 & 90,9 & 1 & 9,1 & 11 & 100 & \\
\hline & Tinggi & 40 & 76,9 & 12 & 23,1 & 52 & 100 & \\
\hline & Total & 57 & 76 & 18 & 24 & 75 & 100 & \\
\hline \multirow{4}{*}{ Domain 2} & Rendah & 10 & 83,3 & 2 & 16,7 & 12 & 100 & \multirow{4}{*}{0,01} \\
\hline & Sedang & 3 & 27,3 & 8 & 72,7 & 11 & 100 & \\
\hline & Tinggi & 21 & 40,4 & 31 & 59,6 & 52 & 100 & \\
\hline & Total & 34 & 45,3 & 41 & 54,7 & 75 & 100 & \\
\hline \multirow{4}{*}{ Domain 3} & Rendah & 3 & 25 & 9 & 75 & 12 & 100 & \multirow{4}{*}{0,06} \\
\hline & Sedang & 3 & 27,3 & 8 & 72,7 & 11 & 100 & \\
\hline & Tinggi & 29 & 55,8 & 23 & 44,2 & 52 & 100 & \\
\hline & Total & 35 & 46,7 & 40 & 53,3 & 75 & 100 & \\
\hline \multirow{4}{*}{ Domain 4} & Rendah & 5 & 41,7 & 7 & 58,3 & 12 & 100 & \multirow{4}{*}{0,09} \\
\hline & Sedang & 2 & 18,2 & 9 & 81,8 & 11 & 100 & \\
\hline & Tinggi & 28 & 53,8 & 24 & 46,2 & 52 & 100 & \\
\hline & Total & 35 & 46,7 & 40 & 53,3 & 75 & 100 & \\
\hline
\end{tabular}

Pada masing-masing domain dari data di atas diperoleh nilai domain 1 yang mencakup aspek kesehatan fisik, $p=0,18(>0,05)$ menunjukkan nilai yang tidak signifikan. Pada data presentase kepatuhan minum obat yang tinggi tidak mempengaruhi kualitas hidup pasien, beberapa faktor menjadi penyebab hal tersebut di lapangan, pasien TB cenderung lebih berhati-hati dalam beraktifitas karena mudah lelah, jika terdapat batuk atau sesak yang belum sembuh maka dalam terapi akan ditambahkan pengobatan tambahan. Pasien TB umumnya berkeringat pada malam hari sehingga cenderung mengganggu waktu tidur pasien dan terjadi perubahan siklus tidur. Efek samping obat yang bisa saja muncul seperti nyeri pada sendi mengganggu aktivitas dan gerak, gatal-gatal di beberapa atau seluruh bagian tubuh bisa menimbulkan permasalahan yang baru.[7]

Pada domain 2 yang mencakup kesehatan psikologis diperoleh nilai $\mathrm{p}=0,01 \quad(<0,05)$ menunjukkan nilai yang signifikan. Di mana kepatuhan minum obat yang baik akan menghasilkan kualitas hidup yang baik. Pasien TB yang belum mendapat pengobatan datang ke puskesmas dalam keadaan berat badan kurang, nafsu makan menurun, batuk berdahak disertai darah, benjolan di bagian kelenjar sehingga bagi sebagian pasien menimbulkan rasa kurang percaya diri, malu karena bentuk tubuh yang berubah. Setelah mendapat terapi, perlahan-lahan berat badan mulai naik dikarenakan nafsu makan yang lebih baik, serta berkurangnya batuk yang menjadi ketidaknyamanan bagi penderita dan sekitarnya. Perubahan ini perlahan diikuti dengan kemampuan untuk dapat menerima kondisi tubuh, berkomunikasi dengan keluarga terdekat dan mampu berkonsentrasi saat beraktifitas.

Pada domain 3 yang mencakup hubungan sosial diperoleh nilai $p=0,06(>0,05)$ dengan hasil yang tidak signifikan. Pengobatan tuberkulosis merupakan pengobatan jangka panjang sehingga 
dukungan moril dari keluarga terdekat, sahabat ataupun tetangga sangat diperlukan. Bagi pasangan suami-istri aktivitas seksual pasti berpengaruh. Bagi pasien perempuan penting untuk diedukasi terkait pencegahan kehamilan untuk mencegah kehamilan yang membawa janin dengan tuberculosis. Dari lingkungan di mana masyarakat yang tidak paham baik tentang penyakit tuberkulosis, penyebaran serta percegahan dikhawatirkanakan mengambil tindakan untuk menjauh serta mencegah orang lain untuk berdekatan dengan pasien TB tersebut. Perasaan terkucilkan umumnya akan menimbulkan perasaan takut, merasa sendiri sehingga akan memicu rasa depresi yang bisa memperparah kondisi kesehatan. Oleh karenanya, diperlukan kepatuhan minum obat sehingga mempercepat proses penyembuhan.

Pada domain 4 yang mencakup hubungan dengan lingkungan diperoleh nilai $p=0,09(>0,05)$ memberikan nilai tidak signifikan. Hal ini dipengaruhi dalam kondisi ketika aktifitas fisik terbatas kemampuan untuk produktif berkurang sehingga memberikan dampak pada keadaan keuangan pasien. Meskipun pengobatan TB yang disalurkan melalui puskesmas tersebut gratis pasien tetap mengeluarkan dana untuk keperluan lain-lain, misalnya foto rontgen, suplemen tambahan yang tidak dibiayai pemerintah, serta alat pembayaran transportasi dari dan ke puskemas.

Di lapangan tingkat kesembuhan pasien dapat diteliti berdasarkan pemeriksaan dahak ataupun pemeriksaan radiologik. Pada penelitian ini pasien masih dalam tahap pengobatan sehingga yang menjadi rujukan adalah pemeriksaan dahak yang dilakukan setelah fase intensif dua bulan. Dari pemeriksaan tersebut diperoleh $96 \%$ pasien menunjukkan perubahan nilai dari positif menjadi negatif yang menjadi parameter hilang tidaknya bakteri dalam dahak serta berhentinya batuk yang selama ini mengganggu. Hal ini bisa menjadi salah satu tolak ukur kualitas hidup, di mana hasil yang positif selama pengobatan akan memberikan dampak positif bagi psikologis pasien, namun di sisi lain dapat menjadi kekhawatiran menurunnya kepatuhan minum obat yang disebabkan karena merasa sudah sembuh hanya dengan nilai tersebut. Dari hasil ini terlihat adanya korelasi antara kuesioner MMAS-8 dan WHOQOL-BREF terkait kepatuhan minum dan kualitas hidup hidup pasien TB.

Hal ini sejalan dengan penelitian yang dilakukan oleh Sari dkk. [22] di RSUD Arifin Ahmad Pekanbaru tentang hubungan kepatuhan minum obat dengan kualitas hidup penderita MDR-TB yang memberikan nilai signifikan $(p=0,03)$ menggunakaan WHOQOL-BREF dan MMAS-8 dan penelitian Hilka dkk [23]tentang hubungan kualitas hidup dengan kepatuhan minum obat pada pasien TB di Afrika Selatan menunjukkan ada hubungan positif antara kepatuhan dan HRQOL pada TB di Afrika Selatan, namun hubungan ini sangat lemah, kemungkinan besar karena HRQOL dipengaruhi oleh sejumlah faktor yang berbeda dan tidak terbatas pada efek kepatuhan. Oleh karena itu, penanganan pasien TB seharusnya didapatkan selain pengobatan yang memadai, juga pemenuhan kebutuhan mental dan psikososial yang spesifik.

Penelitian yang dilakukan oleh Mamani dkk [24] menunjukkan bahwa pengobatan TB selama 6 bulan tidak berpengaruh signifikan terhadap kualitas hidup pasien TB $(\mathrm{p}=0,07)$ di mana kualitas hidup terendah didapatkan pada domain fisik. Hal ini disebabkan efek samping obat seperti INH dan Rifampisin yang menyebabkan disfungsi hati yang menyebabkan kualitas hidup yang rendah pada domain fisik. Pada penelitian tersebut juga dijelaskan alasan lain tetap rendahnya kualitas hidup setelah masa pengobatan 6 bulan mungkin berhubungan dengan dampak psikologi dari penyakit, di mana terjadi isolasi dari komunitas dan keluarga yang dapat mencetus terjadinya depresi. Meskipun belum ditemukan penelitian yang jelas mengenai hubungan kepatuhan pengobatan TB dengan kualitas hidup namun menjalani pengobatan secara rutin terbukti menurunkan angka morbiditas dan mortalitas akibat penyakit TB. 


\section{Kesimpulan}

Berdasarkan kuesioner MMAS-8, 69\% pasien tuberkulosis termasuk memiliki kepatuhan tinggi, $15 \%$ kepatuhan sedang dan 16\% kepatuhan rendah. Dari 6 faktor karakteristik yang dipelajari 2 faktor yang secara signifikan mempengaruhi minum OAT yaitu jenis kelamin $(p=0,014)$ dan pekerjaan $(\mathrm{p}=0,035)$. Berdasarkan hasil analisis hubungan kuesioner MMAS-8 dan WHOQOLBREF, hanya domain 2 yang mencakup aspek kesehatan psikologis yang berpengaruh secara bermakna terhadap kepatuhan minum OAT (p 0,011)

\section{Ucapan Terima Kasih}

Ucapan terima kasih kepada staf Puskesmas Ibrahim Adji dan Puskesmas Gumuruh atas arahan dan panduan selama penelitian dilakukan dan seluruh pihak yang tidak dapat disebutkan satu per satu

\section{Referensi}

[1] S. Price, Patofisiologi: Konsep Klinis Proses-Proses Penyakit. Jakarta: EGC, 2012.

[2] World Health Organization, "Global Tuberculosis Report," Geneva, 2007.

[3] World Health Organization, "Global Tuberculosis Report," Geneva, 2017.

[4] S. L. James, D. Abate, K. H. Abate, and E. Al, "Global, regional, and national incidence, prevalence, and years lived with disability for 354 diseases and injuries for 195 countries and territories, 1990-2017: a systematic analysis for the Global Burden of Disease Study 2017," Lancet, 2018, doi: 392;1789-858.

[5] J. T. DiPiro, Pharmacotherapy: A Pathophysiologic Approach, 9th ed. New York: McGraw-Hill Education, 2014.

[6] M. Hasan, Winariani, and S. Hariadi, Buku Ajar Ilmu Penyakit Paru, 2nd ed. Surabaya: FK UNAIR, 2010.

[7] B. G. Wells, J. T. DiPiro, and T. L. Schwinghammer, Pharmacotherapy Handbook, 9th ed. New York: McGraw-Hill Education, 2015.

[8] World Health Organization, ADHERENCE TO LONG-TERM THERAPIES, Evidence for action. Geneva, 2003.

[9] Depkes and RI, Pedoman Nasional Penanggulangan Tuberkulosis, 2nd ed. Jakarta: Gerdunas TB, 2007.

[10] S. . Lwanga and S. Lemeshow, Sample Size Determination in Health Studies. Geneva: World Health Organization, 1991.

[16] Notoatmodjo, Promosi Kesehatan dan Ilmu Perilaku. Jakarta: PT. Rineka Cipta, 2007.

[17] R. J. Gatchel, An Introduction To Health Psychology 2nd edition. McGraw-Hill Education, 1990.

[18] J. . Morisky, D.E., Ang, A., Wood, M.K., Ward, "Predictive Validity of A Medication Adherence Measure in an Outpatient Setting," 2009, [Online]. Available: https://www.ncbi.nlm.nih.gov/pmc/articles/PMC2562622.

[19] A. Hayati, "Evaluasi Kepatuhan Berobat Penderita Tuberkulosis Paru Tahun 2010-2011 di Puskesmas Kecamatan Pancoran Mas Depok," Jakarta, 2011.

[20] D. . Laily, D. Rombot, and B. Lampus, "Karakteristik Pasien Tuberkulosis Paru di Puskesmas Tuminting Manado," Kedokt. Komunitas dan Trop., vol. 3, no. 1, pp. 1-5, 2015.

[21] F. Panjaitan, "Karakteristik Penderita Tuberkulosis Paru Dewasa Rawat Inap Di Rumah Sakit Umum Dr. Soedarso Pontianak Periode September - November 
2010," J. Mhs. PSPD FK Univ. Tanjungpura, vol. 1, no. 1, 2013.

[22] P. P. Kondoy and E. Al, "Faktor-faaktor yang berhubungan dengan kepatuhan berobat pasien Tuberkulosis Paru di Lima Puskesmas di Kota Manado," J. Kedokt. Komunitas dan Trop., vol. 2, no. 1, 2014.

[22] J. J. Gross and R. . Thompson, Handbook of Emotion Regulation. New York: Guilford Press, 2016.

[23] S. Safii, T. . Putri, and T. . Suparto, "Gambaran Kepatuhan Pasien Tuberkulosis Paru Terhadap Regimen Teraupetik di Puskesmas Padasuka Kota Bandung," ejournal.upi.edu, 2015, [Online]. Available: http:/ / ejournal.upi.edu/index.php/JPKI .

[24] P. D. Sari, D. Karim, and J. Ernawati, "Hubungan Kepatuhan Minum Obat dengan Kualitas Hidup Penderita Tb-MDR di Poli Tb-MDR RSUD Arifin Ahmad Pekanbaru," J. Online Mhs., vol. 5, 2017.

[25] T. Kastien-Hilka, B. Rosenkranz, and E. Sinanovic, "Association between HealthRelated Quality of LIfe and Medication adhrence in Pulmonary Tuberculosis in South of Africa," Front Pharmacol, vol. 8, 2017, doi: 10.3389/fphar.2017.00919.

[26] M. Mamani, M. M. Majzoobi, and F. Keramat, "Assesment of Health-related Quality of Life among Patients with Tuberculosis in Hamadan, Western Iran," Oman Med. J., vol. 29, no. No 2, pp. 102-105, 2014, doi: 10.5001/omj.2014.25.

[26] L. Jamayanti, “Karakteristik Penderita Tuberkulosis Paru di Poliklinik Paru Rumah Sakit Umum Daerah Dr. Zainoel Abidin Banda Aceh Periode Januari-Mei 2014," UNSYIAH, Aceh, 2014.

[27] World Health Organization, "The World Health Organization Quality Of Life (WHOQOL)-BREF," 2004. http://www.who.imt/substance_abuse/research_tools/en/indonesian_whoqol .pdf. 